\title{
Development of an animal drawn manure spreader cum cart
}

\author{
S.T. PATIL AND P.A. MUNDE
}

Received : 16.05 .2017 ; Revised : 26.08.2017; Accepted : 12.09 .2017

See end of the Paper for authors' affiliation

Correspondence to :

\section{S.T. PATIL}

Department of Farm Power and Machinery, Dr. Panjabrao Deshmukh Krishi Vidyapeeth, AKOLA (M.S.) INDIA Email : sagartpati1111@ gmail.com
ABSTRACT : The research work and testing was undertaken at the site of the AICRP on UAE CAET, V.N.M.K.V., Parbhani.The developed Manure spreader consist a chassis having two iron wheels, axel assembly, bearing, flat type agitator, peg tooth agitator, body frame for mounting the trapezoidal shaped manure box, hitching system, and tool box. The application rate of manure varies from 2.46 to $10.06 \mathrm{t} / \mathrm{ha}$ for varies in opining area of cover $0.04 \mathrm{~m}^{2}$ to $0.16 \mathrm{~m}^{2}$. The co-efficient of variation of uniformity for manure distribution varied from $18-20 \%$. The designed manure spreader cum cart gave desired manure application rate $(9-10 \mathrm{t} / \mathrm{ha})$ at an opining area of cover $0.16 \mathrm{~m}^{2}$ at the operational speed of $2.63 \mathrm{~km} / \mathrm{hr}$ and draft required was $637 \mathrm{~N}$. The draft and power requirement of manure spreader were $637 \mathrm{~N}$ and $0.46 \mathrm{~kW}$, respectively within the draft ability limit of pair of bullock. The field capacity and field efficiency of machine were $0.21 \mathrm{ha} / \mathrm{hrand} 84 \%$ at operational speed $2.51 \mathrm{~km} / \mathrm{hr}$. The manure spreader cum cart was used for carting with $500 \mathrm{~kg}$ load on Tar road and Kaccha road by Red Kandhari bullocks. The draft observed for Tar road with no load and $500 \mathrm{~kg}$ load conditions by Red Kandhari bullocks was 37 and $41 \mathrm{~kg}$, respectively. The draft observed on Kaccha road for no load and $500 \mathrm{~kg}$ load conditions was 40 and $48 \mathrm{~kg}$, respectively by Red Kandhari bullocks. Speed observed on Tar road for no load and $500 \mathrm{~kg}$ load conditions by RK bullock was 4.29 and $3.88 \mathrm{~km} / \mathrm{hr}$, respectively. The speed on Kaccha road was 4.04 and $3.48 \mathrm{~km} /$ hr, respectively. Power observed for no load and $500 \mathrm{~kg}$ load conditions was 0.40 and 0.43 , respectively for RK bullock on tar road. And 0.43 and $0.48 \mathrm{Kw}$ for no load and $500 \mathrm{~kg}$ load conditions, respectively on Kaccha road for RK bullock. The increased respiration rate and pulse rate was observed after 2 hrs continuous work on tar and Kaccha road is within the safe limit of fatigue score.

- KEY WORDS : FYM, Agitator, Manure box, Cart, Spreader, Field efficiency, Application rate, Draft, Speed

- HOW TO CITE THIS PAPER : Patil, S.T. and Munde, P.A. (2017). Development of an animal drawn manure spreader cum cart. Internat. J. Agric. Engg., 10(2) : 531-536, DOI: 10.15740/HAS/ IJAE/10.2/531-536. 